\title{
Haematopoietic cancer mortality among vehicle mechanics
}

Katherine L Hunting, Helen Longbottom, Shyam S Kalavar, Frank Stern, Eugene Schwartz, Laura S Welch

\begin{abstract}
Objective and Methods-This historical cohort study investigated causes of death among car and mobile equipment mechanics in the District of Columbia's Department of Public Works. Men who were employed for at least one year between 1977 and 1989 were eligible for inclusion in the cohort; follow up was up to the end of 1991. Three cases of leukaemia (index cases) had been reported among these workers before the inception of this study. This research was undertaken to estimate the relative risk of haematological cancer among mechanics working for the District of Columbia.
\end{abstract}

Results-Among the 335 male fleet maintenance workers, the all cause standardised mortality ratio (SMR) was 0.50 (33 observed deaths, $95 \%$ confidence interval (95\% CI) $0.35-0.70)$, and the all cancer SMR was 0.55 (nine deaths, $95 \%$ CI $0 \cdot 25-1 \cdot 05)$. Three deaths from lymphatic and haematopoietic cancer were observed; the SMR was $3.63(95 \%$ CI 0.75-10.63). In the subgroup with highest potential for exposure to fuels and solvents, the SMR for leukaemia and aleukaemia was 9.26 (two deaths, $95 \%$ CI 1.12-33.43), and the SMR for other lymphatic and haematopoietic neoplasms was 2.57 (one death from malignant lymphoma, 95\% CI 0.06-14-27). All three lymphatic and haematopoietic cancer deaths were among car and mobile equipment mechanics (one was an index case). The two additional index cases were a fourth mechanic who died of leukaemia in 1992 , after mortality follow up ended, and a fifth mechanic who was diagnosed with leukaemia in 1988 and is still alive.

Conclusion-Many garage mechanics in this cohort regularly used petrol to clean parts and to wash their hands; some workers would occasionally siphon petrol by mouth. Benzene, a recognised cause of haematological cancer, is a component of petrol. Previous research indicates that garage mechanics may be at risk of leukaemia and other haematological cancers, presumably due to exposure to petrol; this study supports those findings.

(Occup Environ Med 1995;52:673-678)

Keywords: petrol; benzene; haematopoietic neoplasms
Few studies have examined the mortality experience of garage mechanics. Mechanics generally work for small employers and are unlikely to belong to unions, thus making it difficult to identify sizeable study populations. ${ }^{1}$ Garage mechanics ${ }^{12}$ and other workers exposed to petrol ${ }^{3-5}$ may be at risk of leukaemia and other haematological cancers. This risk is thought to be due to exposure to benzene, which is a recognised cause of haematological cancer and of non-malignant bone marrow injury. ${ }^{6}$ Benzene is a component of petrol, and is used as an antiknock agent in unleaded fuel.

This mortality study was started because of a report of three cases of leukaemia among car and mobile equipment mechanics working for the District of Columbia (DC) ${ }^{8}$ A preliminary evaluation by health department staff showed that the garage mechanics regularly used petrol to clean parts and to wash their hands; these workers also experienced dermal and inhalational exposure to petrol during maintenance of vehicles.

Because of the cluster of cases among mechanics, the potential for exposure to benzene in petrol, and the known leukaemogenic effect of benzene, this mortality study was undertaken. The purpose was to verify whether an excess of deaths from leukaemia had occurred, and to estimate the relative risks of leukaemia and other haematological cancers among these workers.

\section{Methods}

COHORT IDENTIFICATION AND DATA

\section{COLLECTION}

A historical cohort study was conducted to investigate causes of death among employees of the fleet maintenance division of the DC's Department of Public Works (DPW). Because this investigation was motivated by a leukaemia cluster among one job group (mechanics), it was important to use careful and inclusive criteria to define the potentially exposed cohort. Men who were employed for at least one year between 1 January 1977 and 31 December 1989 were eligible for inclusion in the cohort. These dates were chosen as the cohort employment window because it was not feasible to obtain records for years before 1977. Both hourly and salaried employees were included in the study. Due to the small number of women in the fleet maintenance division, they were excluded from the cohort. 
The following information was abstracted from personnel records of potential cohort members: social security number; last name; first name; middle initial; date of birth; sex; date of hire; date of end of employment; all job titles, departments, and organisational codes; and the date of each job change. Three hundred and thirty eight fleet maintenance workers were eligible for inclusion in the cohort.

The personnel records did not include data on race. Information on race was obtained for $90.5 \%$ of cohort members from: (a) medical records (from a concurrent medical screening); (b) death certificates; or (c) coworkers and managers.

\section{VITAL STATUS AND ASCERTAINMENT OF CAUSE} OF DEATH

The follow up period for each person started at the end of one year of employment after 1 January 1977 in a relevant job; thus the earliest date for beginning the follow up was 1 January 1978 . Vital status was initially ascertained up to the end of 1989 ; follow up was subsequently extended to 31 December 1991. The United States National Death Index (NDI) was searched to identify deaths that occurred among cohort members between 1979 and 1991. Also, the 1978 Social Security Administration (SSA) data base was searched to identify deaths that occurred among the few cohort members not employed after 1978. Men were assumed to be alive at the end of the follow up if not identified as deceased through NDI (1979-91) or SSA (1978 only).

To evaluate the completeness of death ascertainment in this population, we checked anecdotal information on coworker deaths supplied by men who had attended a concurrent screening. "Is there anyone whom you used to work with in the 1970 s or early 80 s who has either retired, resigned, or died?") We also listed all men for whom the personnel record identified death as the cause of the end of employment. All deaths identified in the personnel record, and all but two of the deaths mentioned by coworkers, were identified through the NDI or SSA searches.

Death certificates were obtained from the state for all 33 identified deaths. Causes of death were coded by a nosologist according to the international classification of diseases, 9 th revision (ICD-9).

Table 1 Exposure categories for jobs held by fleet maintenance workers in the municipal worker cohort from the District of Columbia

\begin{tabular}{|c|c|c|}
\hline Category & $\begin{array}{l}\text { Levels of exposure to } \\
\text { fuels and solvents }\end{array}$ & Example job titles \\
\hline Office jobs & Low & $\begin{array}{l}\text { Clerk } \\
\text { Purchasing agent } \\
\text { Administrative assistant }\end{array}$ \\
\hline $\begin{array}{r}\text { General garage } \\
\text { environment }\end{array}$ & Medium & $\begin{array}{l}\text { Equipment specialist } \\
\text { Tool and parts attendant } \\
\text { Warehouse worker } \\
\text { Messenger }\end{array}$ \\
\hline $\begin{array}{l}\text { Jobs with regular } \\
\text { exposure to fuels } \\
\text { or solvents }\end{array}$ & High & $\begin{array}{l}\text { Car mechanic } \\
\text { Mobile equipment mechanic } \\
\text { Fuel attendant } \\
\text { Vehicle inspector } \\
\text { Painter }\end{array}$ \\
\hline
\end{tabular}

EXPOSURE CLASSIFICATION

Among the data abstracted from personnel records were position titles, job series codes, and beginning and ending dates for each job change. These data were the basis for each man's exposure history. After a review of position descriptions and discussion of job characteristics with DPW officials and union representatives, each job held in fleet maintenance was assigned a code to indicate a low, medium, or high potential for exposure to fuels and solvents. All jobs involving regular (but not necessarily frequent) contact with fuels or solvents were assigned to the high exposure subgroup. About 180 unique jobs were identified and assigned into one of three categories. Table 1 shows these exposure categories, along with some example job titles.

\section{ANALYTICAL METHODS}

Cause specific standardised mortality ratios (SMRs) were calculated with the National Institute of Occupational Safety and Health (NIOSH) life table analysis system (LTAS), ${ }^{9}$ which generates expected numbers of deaths by cause within five-year age and calendar time periods. Two sided $95 \%$ confidence intervals (95\% CIs) were based upon the Poisson distribution.

District of Columbia death rates were used to calculate expected deaths as most of the cohort lived in DC. Because we were missing data on race for $9.5 \%$ of cohort members, and as $78.8 \%$ of cohort members with known race were black, we elected to use DC comparison rates for non-white men (rather than eliminating workers with unknown race from the analysis).

Analyses of SMRs were carried out for all fleet maintenance workers, and for the high exposure subgroup. The small cohort size prohibited evaluation of SMRs by duration and latency of exposure. Some descriptive comparisons are, however, made.

\section{Results}

Table 2 presents demographic and work history data on the 338 cohort members. As previously stated, most of the cohort members were black. Most cohort members were

Table 2 Demographic and work history characteristics $(n=338)$

\begin{tabular}{lc}
\hline & Men $(\%)$ \\
\hline Race: & \\
Black & $241(71 \cdot 3)$ \\
White & $65(19 \cdot 2)$ \\
Unknown & $32(9 \cdot 5)$ \\
Age at start of follow up: & $62(18 \cdot 3)$ \\
$20-29$ & $113(33 \cdot 4)$ \\
$30-39$ & $96(28 \cdot 4)$ \\
$40-49$ & $52(15 \cdot 4)$ \\
$50-59$ & $12(3 \cdot 6)$ \\
$>60$ & $3(0 \cdot 9)$ \\
Missing age & \\
Year of first fleet & $33(9 \cdot 8)$ \\
maintenance employment: & $108(32 \cdot 0)$ \\
< 1960 & $116(34 \cdot 3)$ \\
1960--9 & $39(11 \cdot 5)$ \\
$1970-9$ & $42(12 \cdot 4)$ \\
$1980-4$ & \\
$1985-8$ &
\end{tabular}


Table 3 Observed deaths and SMRs 1978-91 $(n=335)$

\begin{tabular}{|c|c|c|c|c|}
\hline ICD-9 codes & Underlying cause of death & $\begin{array}{l}\text { Deaths } \\
\text { Observed (n) }\end{array}$ & SMR† & (95\% CI $)$ \\
\hline & All causes & 33 & 0.50 & $(0.35-0 \cdot 70)^{\star \star}$ \\
\hline & All cancers: & 9 & 0.55 & $(0 \cdot 25-1 \cdot 05)$ \\
\hline $150-154$ & Digestive organs and peritoneum & 1 & 0.22 & $(0 \cdot 01-1 \cdot 21)$ \\
\hline $160-165$ & Respiratory system & 2 & 0.33 & $(0.04-1 \cdot 18)$ \\
\hline 185 & Male genital & 2 & 1.91 & $(0 \cdot 23-6 \cdot 88)$ \\
\hline $200-208$ & Lymphatic and haematopoietic & 3 & 3.63 & $(0 \cdot 75-10 \cdot 63)$ \\
\hline 194-199 & Other and unspecified & 1 & 0.49 & $(0 \cdot 01-2 \cdot 70)$ \\
\hline $\begin{array}{r}390-98,402,404 \\
410-14,420-29\end{array}$ & Heart diseases & 12 & 0.75 & $(0 \cdot 38-1 \cdot 30)$ \\
\hline $410,403,405,415-17$, & Other circulatory diseases & 3 & $0 \cdot 70$ & $(0 \cdot 14-2 \cdot 04)$ \\
\hline $460-519$ & Respiratory diseases & 1 & $0 \cdot 28$ & $(0.01-1.57)$ \\
\hline $520-577$ & Digestive diseases & 2 & $0 \cdot 27$ & $(0.03-0.99)^{\star}$ \\
\hline $580-629$ & Genitourinary system diseases & 1 & $0 \cdot 81$ & $(0.02-4.52)$ \\
\hline 730 & Musculoskeletal or connective tissue disorders & 1 & $9 \cdot 15$ & $(0 \cdot 23-50 \cdot 84)$ \\
\hline E800-845, E850-949 & Accidents & 1 & $0 \cdot 35$ & $(0.01-1.96)$ \\
\hline E950-978 & Violence & 2 & $0 \cdot 58$ & $(0 \cdot 07-2 \cdot 10)$ \\
\hline$\S$ & Other causes & 1 & $0 \cdot 24$ & $(0 \cdot 01-1 \cdot 36)$ \\
\hline
\end{tabular}

$\star \mathrm{P}<0.05 ;{ }^{\star} \mathrm{P}<0.01$ based on two sided poisson test.

+ Calculated with the NIOSH LTAS program. Expected deaths based on rates among District of Columbia non-white males. $¥ 95 \%$ CI based on poisson distribution.

$\S$ Residual causes, as classified by the NIOSH LTAS criteria. Categories with zero observed deaths are not listed above.

between 30 and 49 years of age when their follow up started. About $42 \%$ of the workers were first employed before 1970, with an additional 34\% first employed between 1970 and 1979. Three men with missing date of birth were excluded from the SMR analyses. The analyses were based on 3813 person-years of follow up data accumulated between 1978 and 1991. Eighty eight per cent of the person-years were for ages $30-64$.

Thirty three deaths occurred up to the end of 1991. Table 3 shows results of the SMR analysis. The all cause SMR was 0.50 (95\% CI $0.35-0 \cdot 70)$, indicating a pronounced healthy worker effect. The all cancer SMR was similarly low (SMR $=0.55$, nine deaths, $95 \%$ CI 0.25-1.05). Three deaths from lymphatic and haematopoietic cancer occurred in the cohort; the SMR was $3.63 \quad(95 \%$ CI 0.75-10.63).

When we classified jobs into high, medium, and low exposure categories, we did not know that most of the jobs held by male fleet maintenance workers would be high exposure jobs. Two hundred and ninety seven cohort members held at least one job with a high potential for exposure to fuels and solvents; $90 \%$ of the person-years were contributed by these men. The most common high exposure jobs were car and heavy equipment mechanics.

A subgroup analysis of these 297 highly exposed men showed an SMR of $4 \cdot 22$, based on three observed deaths $(95 \%$ CI $0 \cdot 87-12 \cdot 34)$ for lymphatic and haematopoietic cancer (table 4). By more specific causes of death, the SMR for leukaemia and aleukaemia (ICD-9 204-208) in the high exposure subgroup was $9 \cdot 26$ (two deaths, $\mathrm{P}<0.05,95 \% \mathrm{CI}$ 1.12-33.43), and the SMR for other lym- phatic and haematopoietic neoplasms (ICD-9 202-203) was 2.57 (one death, $P>0.05$ ).

We learned through our continued work with this population that one of the index cases died of leukaemia in 1992, after the end of follow up for this study. Another of the three index cases, who was diagnosed with leukaemia in 1988 and received a bone marrow transplant in 1989, is still alive. Although these two cases were not included in the SMR analyses, they do provide additional anecdotal evidence that a haematopoietic cancer risk exists in this cohort of mechanics. Table 5 describes characteristics of the three cases who were included in the SMR analyses, and the two cases who were not. Two were diagnosed with chronic lymphocytic leukaemia, one with chronic myeloid leukaemia, one with acute myeloid leukaemia, and one with nonHodgkins lymphoma. Each of these men worked as a vehicle mechanic in the fleet maintenance division.

Table 5 also presents data on duration and latency of exposure for the five cases. For cases 2,3 , and 4 (who died), we did not have information on date of diagnosis, so we disregarded exposures that occurred within two years of death, to omit most of the effect of exposures that occurred after diagnosis. For cases 1 and 5 , exposure duration and latency were calculated at the date of diagnosis. The length of time worked in fleet maintenance mechanic jobs ranged among the five cases from 11 to about 22 years. Latency was estimated from the first date worked in fleet maintenance mechanic jobs, and ranged from 13 to 34 years. These duration and latency figures consider only fleet maintenance vehicle mechanic jobs. Case 1 had also worked as a car

Table 4 SMRs for lymphatic and haematopoietic cancers high exposure subgroup, $1978-91(n=297)$

\begin{tabular}{lllll}
\hline$I C D-9$ codes & Underlying cause of death & $\begin{array}{l}\text { Deaths } \\
\text { observed }(n)\end{array}$ & $S M R$ & $(95 \%$ CI†) \\
\hline $200-208$ & Lymphatic and haematopoietic cancers & 3 & $4 \cdot 22$ & $(0 \cdot 87-12 \cdot 34)$ \\
$204-208$ & Leukaemia and aleukaemia & 2 & $9 \cdot 26^{\star}$ & $(1 \cdot 12-33 \cdot 43)$ \\
$202-203$ & $\begin{array}{c}\text { Other neoplasms of lymphatic } \\
\text { and haematopoietic tissue }\end{array}$ & 1 & $2 \cdot 57$ & $(0 \cdot 06-14 \cdot 27)$ \\
\hline
\end{tabular}

$\star \mathrm{P}<0.05$ based on two sided poisson test.

$+95 \%$ CI based on poisson distribution. 
Table 5 Known cases of lymphatic and haematopoietic cancers 1978-93

\begin{tabular}{|c|c|c|c|c|c|}
\hline \multirow[b]{2}{*}{ Case } & \multirow[b]{2}{*}{ Diagnosis } & \multirow{2}{*}{$\begin{array}{l}\text { Age and year of } \\
\text { death or diagnosis }\end{array}$} & \multicolumn{2}{|c|}{$\begin{array}{l}\text { Fleet maintenance } \\
\text { mechanic jobs } \ddagger\end{array}$} & \multirow[b]{2}{*}{ Earlier municipal jobs, and years } \\
\hline & & & Duration§ & Latency§ & \\
\hline $1^{\star}$ & $\begin{array}{l}\text { Chronic myeloid } \\
\text { leukaemia }\end{array}$ & $\begin{array}{l}\text { diagnosed } 1988 \\
\text { age } 38\end{array}$ & 13 & 13 & $\begin{array}{l}\text { Car mechanic with various } \\
\text { DC departments, } 1972-5\end{array}$ \\
\hline $2^{\star} \dagger$ & $\begin{array}{l}\text { Acute myeloid } \\
\text { leukaemia }\end{array}$ & $\begin{array}{l}\text { died } 1990 \\
\text { age } 47\end{array}$ & 15 & 15 & $\begin{array}{l}\text { Incinerator labourer, 1962-6 } \\
\text { Sanitation department lorry driver, 1966-77 } \\
\text { Incinerator lorry driver, 1967-70 } \\
\text { Fleet maintenance lorry driver } \\
\text { (high solvent exposure), 1970-3 }\end{array}$ \\
\hline $3+$ & Malignant lymphoma & $\begin{array}{l}\text { died } 1991, \\
\text { age } 69\end{array}$ & $22 ף$ & 329 & $\begin{array}{l}\text { Fleet maintenance labourer (high solvent } \\
\text { exposure), } 1949 \sim 1956\end{array}$ \\
\hline $4 \dagger$ & $\begin{array}{l}\text { Chronic lymphocytic } \\
\text { leukaemia }\end{array}$ & $\begin{array}{l}\text { died } 1991 \\
\text { age } 72\end{array}$ & 19 & 30 & No previous municipal jobs \\
\hline $5^{\star}$ & $\begin{array}{l}\text { Chronic lymphocytic } \\
\text { leukaemia }\end{array}$ & $\begin{array}{l}\text { diagnosed } 1989, \\
\text { died } 1992, \\
\text { age } 61\end{array}$ & 11 & 16 & $\begin{array}{l}\text { Sanitation department labourer, 1966-71 } \\
\text { Sanitation department maintenance worker, } \\
\text { 1971-3 }\end{array}$ \\
\hline
\end{tabular}

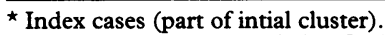

t These three cases included in SMR analysis (see tables 3 and 4).

These three cases included in SMR analysis (see tables 3 and 4 ).
Includes work as a vehicle mechanic only in the fleet maintenance division. Other fleet maintenance and non-fleet maintenance ¥ Includes work as a vehicle mechanic only in the
municipal jobs are included in right hand column.

$\S$ In estimating duration and latency, exposures occurring within two years of death were omitted for cases 2,3 , and 4 .

Tी Both estimates are approximate.

mechanic in other DC departments before his fleet maintenance job. Before becoming mechanics, cases 2 and 3 had non-mechanic fleet maintenance jobs that were rated as having high potential for exposure to fuels or solvents.

There were too few haematopoietic cancer deaths to evaluate SMRs by duration and latency in the LTAS analysis. We did, however, compare mean duration worked in jobs with high exposure to fuel or solvents between the five cases of haematopoietic cancer and the other 292 cohort members in the high exposure subgroup. The five cases had spent an average of 18.2 years in high exposure jobs, whereas other members of the high exposure sub-cohort had worked for an average of $13 \cdot 1$ years. This difference of $5 \cdot 1$ years between the groups was not significant (Students $t$ test, $\mathrm{P}=0 \cdot 17$ ).

\section{Discussion}

\section{MORTALITY RISKS}

We report an excess of lymphopoietic neoplasms among vehicle mechanics. The SMR of $4.22(95 \%$ CI $0.87-12.34)$ in the group with high exposure to solvents and fuels indicates a potentially high relative risk for haematopoietic cancer among these workers. This risk estimate was based on only three deaths. A further analysis by cancer subtype indicated the highest risk (SMR $=9 \cdot 26,95 \%$ CI 1.12-33.43) for the category leukaemia and aleukaemia, a result based on only two deaths. Although we had information on each worker's exposure history, there were too few deaths to allow subgroup analyses by latency and duration of exposure.

This study was motivated by knowledge of a cluster of three leukaemia cases among vehicle mechanics, one of whom had died before 1990 when we began the study. This death, plus the two additional deaths identified by the 1978-91 mortality follow up, form the basis for the SMR results presented above. As our objective was to estimate a relative risk for this cohort of workers exposed to petrol, we included the index case in the analysis.

Two cases of haematological malignancy exist in this cohort besides the three considered in the mortality analysis. One was an index case for the investigation and is alive after a bone marrow transplant for chronic myeloid leukaemia, and another index case died of chronic lymphocytic leukaemia in 1992 after the end of the follow up period. These additional cases provide support for the conclusion that a high risk of haematopoietic cancers exists in this group of workers.

Several earlier studies have reported an excess of haematological malignancy in garage mechanics and petrol station attendants, the results of which support the conclusions of this investigation. Milham ${ }^{2}$ analysed death certificates in Washington State, and found four occupational groups with petrol or fuel exposures to have excess risks for numerous haematopoietic cancers. Car mechanics were found to have significant excesses of lymphatic leukaemia (proportionate mortality ratio (PMR) 283) and other lymphomas (PMR 175), and non-significant excesses for Hodgkin's disease, myeloid leukaemia, acute leukaemia, and unspecified leukaemia.

Analysing deaths in the state of New Hampshire, Schwartz ${ }^{1}$ found a PMR of 176 for leukaemia among car mechanics alone ( $P$ $>0.05$ ), and a PMR of 328 for all workers in the petrol service station industry combined ( $P$ $<0.05)$. An Italian cohort of filling station managers was found to have an excess of nonHodgkin's lymphoma (not significant). ${ }^{10}$ Jakkobson et $\mathrm{al}^{3}$ linked occupational data and mortality data in Sweden to identify occupational groups at increased risk of acute myeloid leukaemia, and found a relative risk of $3.6(95 \%$ CI $1 \cdot 7-6.6)$ for petrol attendants. Two case-control studies also found an excess of exposure to petrol among cases of acute myeloid leukaemia. ${ }^{45}$ The use of petrol as a solvent or cleaner has also been linked to cases of malignant and non-malignant blood disorders. ${ }^{81112}$

Studies of refinery workers also suggest that exposure to petroleum products can cause haematological malignancy. A review of these studies by the Environmental Protection Agency concluded that they collectively sup- 
port an association between employment in a petroleum refinery and risk of cancer of the lymphatic and haematopoietic tissues. ${ }^{13}$

In this cohort study, the three deaths from haematological neoplasms include an acute myeloid leukaemia, a chronic lymphocytic leukaemia, and a malignant lymphoma. There is strong evidence from case reports and epidemiological studies dating back for many years that acute myeloid leukaemia is linked to benzene exposure. ${ }^{14-19}$ Epidemiological studies have reported an excess of chronic myeloid leukaemia and chronic lymphocytic leukaemia. ${ }^{20-22}$ Non-Hodgkin's lymphoma has also been linked to benzene exposure in both case series and epidemiological studies..$^{20-28}$ Also, animal studies show effects of benzene on lymphocyte number and function. ${ }^{29} \mathrm{We}$ therefore think that the evidence warrants grouping all lymphatic and haematopoietic cancer deaths from our mortality follow up; Wong $^{27}$ and Decoufle et $a l^{30}$ have also advanced this approach.

This study is limited by the small cohort size and small number of deaths. Also, as the short term survival rate for some haematopoietic cancers such as chronic lymphocytic leukaemia is relatively high, it would have been desirable to conduct a cancer incidence study, rather than a mortality study. The lack of established local cancer registries precluded this option, and this study must be interpreted in the context of haematopoietic cancer mortality only.

Another consideration is the completeness of mortality data. The United States National Death Index, which has been shown to identify $97 \%$ of deaths when the social security number is available, ${ }^{31}$ was used for 1979-91. Social Security death tapes were used to identify deaths that occurred in 1978. Cohort members not identified as deceased were assumed to be alive, an assumption that could result in artificially low SMRs if any deaths were not ascertained. The SMR analysis showed risks lower than one for most causes of death, indicating either underascertainment of deaths, or more likely, a pronounced healthy worker effect. Even so, the rates of haematopoietic cancer in this cohort were considerably increased.

We were missing data on race for $9.5 \%$ of the cohort members, and based our SMRs on non-white male comparison rates, rather than eliminating men of unknown race. The lack of adjustment for about $20 \%$ of the cohort who were white has resulted in slight error in estimating the expected numbers for the SMRs. During the time period of interest, the rates for lymphatic and haematopoietic cancers differed by less than $20 \%$ between white and non-white men, and were not systematically higher for one group than the other. Given these similarities, the SMRs for haematopoietic cancer are likely to be only slightly confounded by race.

EXPOSURE TO PETROL AND BENZENE

Potential for exposure to petrol and other fuels and solvents has been inferred from job title information found in each worker's personnel record. Assignment of an exposure rating to each job title was based upon a review of detailed job descriptions, and discussions with workers and management, but probably involves some exposure misclassification. We were particularly anxious to establish the high exposure subgroup. Thus the degree of exposure variability in this subgroup is probably substantial.

In the United States, the benzene content in petrol currently averages $1 \cdot 5-2 \cdot 0 \%$ by volume and may range up to $5 \% .{ }^{32} 33$ In addition to petrol, the fleet maintenance workers were potentially exposed to several other toxic agents. ${ }^{34}$ Mechanics could have had exposure to other degreasing agents, diesel fuel, asbestos from brake work, and used motor oils. Varsol, a degreasing solvent that contains $1 \%$ benzene, was used at one time in some of the garages. ${ }^{34}$ Other solvents such as spray cans of brake, battery, or carburettor cleaner were also used for short periods of time. A few of the fleet maintenance workers would have experienced other exposures during welding, spray painting, sheet metal work, carpentry, and tyre repair operations. Except for petrol and Varsol, there is no evidence of haematopoietic cancer risk associated with the exposures in city garages.

Research ${ }^{35-38}$ showing that dermal contact with petrol or benzene can result in significant benzene absorption is very relevant for our cohort members, who immersed their hands in petrol or used a petrol saturated rag to clean parts, resulting in potentially prolonged skin contact. Until recently, these garage mechanics regularly used petrol or a mixture of petrol and transmission fluid to clean engine parts and to wash their hands. Occasionally, some workers would also siphon petrol by mouth. When we surveyed active workers in 1990, $63 \%$ of the 82 mechanics reported having ever washed their hands with petrol, and $12 \%$ reported this as a current practice. Similarly, $51 \%$ of mechanics reported ever and $11 \%$ reported currently siphoning petrol by mouth. (Before our survey, the DPW instructed all mechanics to stop using petrol as a cleaner and removed the petrol barrels from the garage.)

Occupational exposure to benzene is restricted to an eight hour time weighted average (TWA) of $1 \mathrm{ppm}$ in the United States. ${ }^{39}$ There are an estimated 1.2 million car, bus, and lorry mechanics, plus 200000 garage and service station mechanics in the United States ${ }^{40}$ who are exposed to benzene but who are not protected by the Occupational Safety and Health Administration standard. ${ }^{39}$

We do not have quantitative estimates of exposure to petrol or benzene for this group of workers. The only benzene exposure data that we are aware of for garage workers come from Sweden, where eight hour TWA exposures of $0.3-2.3 \mathrm{ppm}$ and $0.1-0.5 \mathrm{ppm}$ were found during the winter and summer, respectively. ${ }^{41}$ Some tasks were found to involve higher peak exposures of up to $5 \mathrm{ppm}$. Further quantitative exposure data for garage workers would be very valuable. These data would provide infor- 
mation on the dose-response relation for haematopoietic cancers related to benzene and would also help to determine the degree of cancer risk faced by other garage mechanics. We are not aware of industrial hygiene data for garages that would allow a retrospective analysis.

Exposure of mechanics to petrol can be greatly reduced through use of alternative work practices and improved equipment and facilities. These include use of safer degreasing solvents, appropriate hand washing facilities, protective clothing, gloves or barrier creams, mechanical pumps, covers for containers and tanks containing solvents, improved ventilation, and if necessary, appropriate respirators. This study found a fourfold excess of haematopoietic cancer among workers exposed to fuel and solvents, and supports previous evidence that garage mechanics may be at risk of work related haematopoietic cancers. Priority should be given to reducing the workplace hazards faced by these workers.

This study was initiated with contract support from the DC Department of Human Services. We appreciate the assistance provided by the following people and organisations: Beth Dysert-Laven of NIOSH; Dr Peter Infante of OSHA; Gwen Allen of the DC Department of Public Works; Judy Banks and Jola Harris of the DC Department of Personnel; Charles Davis of the DC Office of Pay and Retirement; and finally, the members and officers of the three union locals involved AFGE Locals 631 and 1975 and AFSCME Local 2091.

1 Schwartz E. Proportionate mortality analysis of automobile mechanics and gasoline service station workers in New mechanics and gasoline service station wor.

2 Milham S, Jr. Occupational mortality in Washington State 1950-79. Cincinnati, OH: National Institute of Occupational Safety and Health, DSHEFS, 1983. (NTIS No PB84-199769.)

3 Jakobsson R, Ahlbom A, Bellander T, Lundberg I. Acute myeloid leukemia among petrol station attendants. Arch Environ Health 1993;48:255-9.

4 Brandt L, Nilsson PG, Mitelman F. Occupational exposure to petroleum products in men with acute non-lymphocytic leukaemia. $B M \Im$ 1978;1:553-4

5 Flodin U, Andersson L, Anjou CG, Palm UB, Vikrot $O$ Axelson $O$. A case-referent study on acute myeloid leukemia, background radiation exposure and exposure leukemia, background radiation exposure and exposure to solvents and other

Health 1981;7:169-78.
6 International Agency for Research on Cancer. Some industrial chemicals and dyestuffs. LARC Monogr Eval Carcino Risk Chem Hum 1982;29:93-148.

7 Environmental Protection Agency. Drinking water criterio document on benzene. Final draft, PB86-118122. Washington, DC: US Environmental Protection Agency, Office of Drinking Water, 1985.

8 Infante PF, Schwartz E, Cahill R. Benzene in petrol: a continuing hazard [letter]. Lancet 1990;336:814-5.

9 Steenland K, Beaumont J, Spaeth S, Brown D, Roscoe R Stayner $\mathrm{L}$, et al. User documentation: life table analysis system, version $F$. Cincinnati, Ohio: USDHHS/PHS/CDC NIOSH/DSHEFS, 1991.

10 Lagorio S, Forastiere F, lavarone I, Rapiti E, Vanacore N, Perucci CA, Carere A. Mortality of filling station attendants. Scand $\mathcal{f}$ Work Environ Health 1995;20:331-8.

11 Verwilghen RL, Van Dorpe A, Veulemans H. Dangers of petrol used as solvent. Lancet 1975;2:1156.

12 Van den Berghe H, Louwagie A, Broeckaert-Van Orshoven A, David G, Verwilghen R. Chromosome analysis in two unusual malignant blood disorders presumably induced by benzene. Blood 1979;53:558-66.

13 Environmental Protection Agency. Evaluation of the carcinogenicity of unleaded gasoline. Washington, DC: EPA, 1987.

14 Aksoy M, Dincol K, Erdem S, Akgun T, Dincol G. Details of blood changes in 32 patients with pancytopenia associated with long-term exposure to benzene. $\mathrm{Br} \mathcal{F}$ Ind $M e d$ 1972;29:56-64.

15 Aksoy M, Erdem S, Dincol G. Leukemia in shoe-workers exposed chronically to benzene. Blood 1974;44:837-41.

16 Infante PF, Rinsky RA, Wagoner JK, Young RJ. Infante PF, Rinsky RA, Wagoner JK, Young

17 Ott MG, Townsend JC, Fishbeck WA, Langner R Mortality among individuals occupationally exposed to benzene. Arch Environ Health 1978;33:3-9.

18 Vigliani EC, Saita G. Benzene and leukaemia. $N$ Engl $\mathcal{F}$ Med 1964;271:872-6.

19 Yin SN, Li GL, Tain FD, Fu ZI, Jin C, Chen YJ, et al. A retrospective cohort study of leukemia and other cancers in benzene workers. Environ Health Perspect 1989;82: 207-13.

20 McMichael AJ, Spirtas R, Kupper LL, Gamble JF. Solvent exposure and leukemia among rubber workers: an epidemiologic study, 7 Occup Med 1975;17:234-9.

21 Arp EW Jr, Wolf PH, Checkoway $\mathrm{H}$. Lymphocytic leukemia and exposures to benzene and other solvents in industry. F Occup Med 1983;25:598-602.

22 Wolf PH, Andjelkovic D, Smith A, Tyroler H. A case-control study of leukemia in the US rubber industry. $\mathcal{O}$ Occup Med 1981;23:103-8.

23 Aksoy M. Malignancies due to occupational exposure to benzene. Am F Ind Med 1985;7:395-402.

24 Vianna NJ, Polan A. Lymphomas and occupational benzene exposure. Lancet 1979;1:1394-5.

25 Norseth $T$. Cancer incidence in the rubber industry in Norway. Scand $₹$ Work Environ Health 1983;2:69-71.

26 Young N. Benzene and lymphoma [letter]. Am ₹ Ind Med 1989;15:495-8.

27 Wong $\mathrm{O}$. An industry wide mortality study of chemical workers occupationally exposed to benzene. I General results. Br f Ind Med 1987;44:365-81.

28 Yin SN, Li GL, Tain FD, Fu ZI, Jin C, Chen YJ, et al. Leukaemia in benzene workers: a retrospective cohort study. Br f Ind Med 1987;44:124-8.

29 Young NS. Drugs and chemicals as agents of bone marrow failure. In: Testa NG, Gale RP, eds. Hematopoiesis. Long-term effects of chemotherapy and radiation. New York: Marcel Dekker, 1988;131-57.

30 DeCoufle P, Blattner WA, Blair A. Mortality among chemical workers exposed to benzene and other agents. Environ Res $1983 ; 30: 16-25$.

31 Boyle CA, DeCoufle P. National sources of vital status information: extent of coverage and possible selectivity in reporting. Am $\mathcal{A}$ Epidemiol 1990;131:160-8.

32 Infante PF. State of the science on the carcinogenicity of gasoline with particular reference to cohort mortality study results. Environ Health Perspect 1993;101(supp 6):105-9.

33 Citizens Fund. Cancer at the pump: benzene and aromatics in gasoline, part ii. Washington, DC: Citizens Fund, 1990.

34 National Institute for Occupational Safety and Health. Final report, health hazard evaluation, District of Columbia Final report, health hazard evaluation, District of Columbia department of public works, fuly $5-6$ and 19, 1990. HETA

35 Blank IH, McAuliffe DJ. Penetration of benzene through human skin. $\mathcal{F}$ Invest Dermatol 1985;85:522-6.

36 Susten AS, Dames BL, Burg JR, Niemeier RW. Percutaneous penetration of benzene in hairless mice: an estimate of dermal absorption during tire-building operations. Am F Ind Med 1985;7:323-35.

37 Maibach HI, Anjo DM. Percutaneous penetration of benzene and benzene contained in solvents used in the rubber industry. Arch Environ Health 1981;36:256-60.

38 Franz TJ. Percutaneous absorption of benzene. In MacFarland HN, Holdsworth CE, MacGregor JA, et al, eds. Advances in modern environmental toxicology. Vol vi. eds. Advances in moderm environmental toxicology. Vol vi. Applied toxicology of petroleum hydrocarbons. Pring
Princeton Scientific Publishers, 1984;61-70.

39 Occupational Safety and Health Administration Department of Labor. Occupational exposure to benzene; final rule. Friday, 11 September, 1987. Fed Reg 1987;29 (CFR Part 1910):34460-578.

40 Bureau of Labor Statistics. Employment and eamings. Vol 37. Washington, DC: US Department of Labor, 1990 186-8.

41 Holmberg B, Lundberg P. Benzene: standards, occurrence, and exposure. Am $\mathcal{F}$ Ind Med 1985;7:375-83. 